\title{
Chemical and organoleptic potentials of soups based on cowpea leaves and husks.
}

\author{
Igbatim, C.A. ${ }^{1}$; Chikwendu, J. N. ${ }^{2}$; And Obizoba, I. C ${ }^{3}$ \\ 1. Department of Home Science, Nutrition and Dietetics, University of Nigeria, Nsukka, Nigeria \\ 2. Department of Home Science, Nutrition and Dietetics, University of Nigeria, Nsukka, Nigeria \\ 3. Department of Home Science, Nutrition and Dietetics, University of Nigeria, Nsukka, Nigeria
}

\begin{abstract}
Chemical and organoleptic potentials of soups based on leaves and husks of cowpea (Vigna unguiculata) were investigated. Recipe for preparation of soups was developed during a 7-woman focus group discussion. The soups nutrients and sensory evaluation were based on standard procedures. Moisture for leaves and husks soups was comparable (71.03, 69.88 and $69.95 \%$,). The soup based on dried husks (HS) had higher protein and fat $(p<0.05)$ relative to those soups based on both dried leaves (DS) and fresh leaves $(F S)(10.24$ vs.9.97 and 10.03\%) and (10.24 vs. 9.87 and 9.47\%), respectively. The ash values for all soups were similar $(2.17,2.16$ and 2.27\%) ( $p>0.05)$. Fibre values based on for HS, DS and FS differed significantly $(p<0.05)$ .Carbohydrate levels were low in all soups. The soups had appreciable calcium, phosphorus, iron zinc and iodine. Pro-vitamin A in soup based on fresh leaves had higher value relative to those of dried leaves and husks (1.83vs.1.47 and 1.64RE). Phytochemicals and antinutrients for soups based on cowpea leaves and husks were low. Organoleptic attributes of the three soups were good and generally accepted. Cowpea leaves and husks have high food potentials that could be promoted and diversified.
\end{abstract}

Key words: Chemical, composition, cowpea, organoleptic, soups.

\section{Introduction}

Cowpea (Vigna unguiculata (L) Walp) is grown most commonly for the edible seeds in Africa and in the USA (1). Vegetative harvest of cowpeas provides an alternative to conventional cowpea seed harvest. Young cowpea leaves are consumed in at least 18 countries in Africa and 7 countries in Asia and the Pacific (1). Cowpeas are among the top four leaf vegetables marketed and consumed. It is a low-fat legume species for inclusion in controlled ecological life-support system (CELSS) which provides a more nutrient-dense food relative to other proposed leaf vegetables (1).

Its nutrient content for human consumption was extensively studied. Cowpea leaves are good sources of some amino acids, vitamins, minerals and proteins. Young leaves have higher protein and its dietary fibre increases with leaf age (2). Fat and ash values are less affected. Imungi and Potter (3) studied nutrient contents of raw and cooked cowpea leaves in Kenya. The crude protein was high (32.8 and 34.3\%) as well as iron, calcium, phosphorus and zinc. Levels of ascorbate, total carotene and free total folacin were $410 \mathrm{mg}, 57 \mathrm{mg}$, $334 \mathrm{mg}$, and $2012 \mathrm{mg}$, each per $100 \mathrm{~g}$ of solids. Freshly harvested leaves cooked by a traditional Kenyan technique retained $88 \%$ of their crude protein and substantial quantities of minerals. Losses in ascorbate, free and total folacin were $87 \%, 49 \%$ and $66 \%$. The recoveries in cooking water were $5.6 \%, 20 \%$ and $12 \%$. Carotene in cooked leaf solids increased slightly, an indication of high potential for processing (3).

Cowpeas are among the top four leaf vegetables sold fresh in Ghana. The differences in palatability of cowpea leaves and husks had not been investigated. Many farmers, sometimes in Ghana complained that, improved varieties have bitter or tough leaves and husks that do not make good food (4). This investigation was meant to provide information on the chemical and sensory attributes of local cowpea tender leaves and husks soups consumed in Tiv communities in Benue State, Nigeria.

\section{Processing of cowpea leaves and husks}

\section{Materials And Methods}

The most upper tender leaves and husks (at 40 days) after planting in home garden were selected for use in this study. The fresh tender leaves and pods were plucked and processed for soup preparation.

\section{Soup preparation}

A 7- woman recipe developed during focus group discussion for soup preparation was adopted.

\section{Method of preparation of cowpea leaves and husks soup}

Fresh cowpea leaves $(800 \mathrm{~g})$ were washed, chopped and allowed to stand in hot water for 3 minutes in a ratio of 1:2 (w/v). Water was drained; $750 \mathrm{ml}$ cold water was added to the cooking pot and boiled. Five dessert 
Chemical and organoleptic potentials of soups based on cowpea leaves and husks.

spoons of palm oil, ground melon, chopped onions, ground pepper, fermented locust beans (nune), salt and dry fish were added to the cooking soup. Cowpea leaves were added and cooked for another 10 minutes. When the soup was judged ready for human consumption by taste, it was brought down from fire, cooled and name labeled. An aliquot of the soup was stored frozen for analysis. Another aliquot of the soup was for sensory evaluation. The same ingredients and method were adopted to prepare parboiled and sundried cowpea leaves and husks soups.

\section{Chemical analysis}

Chemical and sensory evaluation of the soups was determined using standard methods (5).

\section{Results And Discussion}

Proximate composition of cowpea soups based on its fresh and dried leaves and husks (\%).

Moisture content of the soups was comparable. It ranged from 69.88 to $71.03 \%$. Protein values for the three soups differed. The soup based on dried leaves had the least $(9.97 \%)$. Fresh leaves and dried husks soups had high and varied values (10.24 and $10.03 \%)$. Dried husks soups had a slight advantage in protein $(0.21 \%)$ (10.24-10.03\%) over that of fresh leaves (Table1). The difference was due to drying which decreased moisture to increase dry matter of which protein is among. Fat value for soups based leaves and husks varied. Husks soup (HS) had higher fat relative to those of fresh and dried leaves (10.24 vs. 9.87 and 9.47\%, each). The slight differences in fat might be influenced by form of the leaves (fresh or dried). Ash values for the three soups differed. The differences were insignificant $(2.16,2.27$ and $2.17 \%$, each) $(\mathrm{P}>0.05)$. Dried leaves soup had a difference of $0.11 \%$ relative to fresh leaves and dried husks soups ( 2.27 vs.2.17 and 2.16\%, each) $(\mathrm{P}<0.05)$. Fibre for the three soups differed. The differences in fibre were not significant $(\mathrm{P}<0.05)$ in the three soups. The husk soup had higher fibre relative to as those of fresh and dried leaves (1.84 vs. 1.77 and $1.68 \%$ ). Carbohydrate value for the FS soup was higher $(\mathrm{P}<0.05)$ relative to DS and HS soups $(6.85$ vs.5.11 and 5.59\%). Soup based on DS had much lower carbohydrate $(5.11 \%)$.

The high protein $(9.97 \%)$ for soups based on dried cowpea leaves and husks $(10.24 \%)$ showed consistency of these nutrients when compared with their processed forms prior to use for soups. This is in agreement with (4). On the other hand, the low fibre (1.77 and 1.84\%) in soups based on dried leaves and husks are simple to explain. Soups contain more water and less dry matter such as fibre, fat and carbohydrate (Table 1).

Table 1: Proximate composition of soups based on cowpea leaves and husks (\%).

\begin{tabular}{lcccccl}
\hline Sample & Moisture (\%) & Protein (\%) & Fat $(\%)$ & Ash (\%) & Fibre (\%) & Carbohydrate (\%) \\
\hline HS & $69.95^{\mathrm{a}} \pm 0.01$ & $10.24^{\mathrm{a}} \pm 0.01$ & $10.24^{\mathrm{a}} \pm 0.01$ & $2.16^{\mathrm{a}} \pm 0.00$ & $1.84^{\mathrm{a}} \pm 0.01$ & $5.59^{\mathrm{a}} \pm 0.01$ \\
DS & $71.03^{\mathrm{b}} \pm 0.00$ & $9.97^{\mathrm{b}} \pm 0.00$ & $9.87^{\mathrm{b}} \pm 0.01$ & $2.27^{\mathrm{a}} \pm 0.00$ & $1.77^{\mathrm{b}} \pm 0.00$ & $5.11^{\mathrm{b}} \pm 0.01$ \\
FS & $69.88^{\mathrm{c}} \pm 0.00$ & $10.03^{\mathrm{c}} \pm 0.0$ & $9.47^{\mathrm{c}} \pm 0.00$ & $2.17^{\mathrm{a}} \pm 0.02$ & $1.68^{\mathrm{c}} \pm 0.01$ & $6.85^{\mathrm{c}} \pm 0.00$ \\
\hline
\end{tabular}

$\mathrm{HS}=$ Husks soup, $\mathrm{DS}=$ Dried leaves soup, $\mathrm{FS}=$ Fresh leaves soup.

means \pm SD of three determinations

Values at the same vertical column with different superscript letters are significantly different $(\mathrm{P}<0.05)$.

\section{Micronutrient content of soups based on cowpea leaves and husks.}

The micronutrient contents of cowpea leaves and husk soups are shown in table 2. Calcium values for the three soups differed. Ca for both the fresh and the dried leaves soups were high and comparable (95.43 and $98.80 \mathrm{mg}$, each). The husk soup (HS) had the highest $\mathrm{Ca}(104.17 \mathrm{mg})$ that varied significantly $(\mathrm{P}<0.05)$ relative to DS and FS soups (104.17 vs.98.80 and $95.43 \mathrm{mg}$, each). The higher Ca (104.17) for HS soup is simple to explain. Most minerals are much more concentrated in husks of cereals and legumes. Cowpea, a legume as such would have high $\mathrm{Ca}$. Phosphorus ( $\mathrm{p}$ ) values were influenced by treatments. P values for HS and FS soups were high and comparable (265.45 and $266.31 \mathrm{mg}(\mathrm{P}>0.05)$. The DS soup had an advantage in phosphorus relative to those of HS and FS (277.11 vs. $265.45 \mathrm{mg}$ and $266.31 \mathrm{mg}$, each). The iron values for the three soups differed significantly $(\mathrm{P}<0.05)$. The husk soup had higher iron $(2.62 \mathrm{mg})$ relative to dried and fresh leaves soups $(2.47$ and $2.35 \mathrm{mg})$. The higher $\mathrm{Fe}(2.62 \mathrm{mg})$ might be that, $\mathrm{Fe}$ is much more concentrated in the husk than in the leaves regardless of treatments. It could also be that, the husk contained very low levels of antinutrients that could chelate $\mathrm{Fe}$ and make it unavailable. Zinc levels for the three soups were generally low (0.22 to $0.25 \mathrm{mg}$ ) and comparable $(\mathrm{P}<0.05)$. The slight increase in $\mathrm{Zn}$ for the DS soup might be attributed to drying which reduces moisture to increase dry matter $(\mathrm{Zn})$. This is a commonly observed fact. Iodine values for the three soups were similar $(0.05$ to $0.07 \mu \mathrm{g} / 100 \mathrm{~g})$. This meant that, neither the husks nor the leaves regardless of treatment had an edge over the other. Pro vitamin A value for fresh leaves soup was higher $(\mathrm{P}<0.05)$ relative to those of dried leaves and husks (1.83 vs. 1.47 and 1.64RE, respectively). The soups based on dried husks and leaves had 
comparable values (1.64 and $1.47 \mathrm{mg}$, each). The fresh leaves soup had higher pro vitamin A because it is known that some micronutrients or their precursors are much more concentrated on the fresh sources (leaves). This could be the reason for the higher pro vitamin A content of fresh leaves soup. Vitamin $\mathrm{C}$ values for the three soups varied and ranged from 0.27 to $0.33 \mathrm{mg} / 100 \mathrm{~g}$. The soup based on husks had higher value $(0.33 \mathrm{mg})$ relative to those of dried leaves $(0.29 \mathrm{mg})$ and fresh leaves $(0.27 \mathrm{mg})$. The differences were not significant $(\mathrm{P}>0.05)$. This observation meant that, the tender pods could be a good source of vitamin $\mathrm{C}$ or even better.

The consistent appreciable mineral values for these three soups (Table 2) suggests that, these soups are fairly good sources of minerals. The high minerals for both the dried tender leaves and their soups agreed with those of various workers who reported that, cowpea leaves are a good source of minerals, especially Fe, Ca, K, P and Zn (Imungi and Potter (4);Ahenkora, Adu- Dapaah \& Agyemang(2); Mamiro et al.(7). On the other hand, the lower vitamin $\mathrm{C}$ in soups based on dried leaves and husks might be due to cooking in large volume of water at high temperature. Water soluble vitamins are lost in large volume of water at high temperature cooking- a usually observed fact.

Table 2: Micronutrient content of cowpea leaves and husks soups per 100g portion

\begin{tabular}{cccccccc}
\hline Sample & $\begin{array}{c}\text { Iron } \\
(\mathrm{mg})\end{array}$ & $\begin{array}{c}\text { Zinc } \\
(\mathrm{mg})\end{array}$ & $\begin{array}{c}\text { Calcium } \\
(\mathrm{mg})\end{array}$ & $\begin{array}{c}\text { Iodine } \\
(\mu \mathrm{g})\end{array}$ & $\begin{array}{c}\text { Phosphorus } \\
(\mathrm{mg})\end{array}$ & $\begin{array}{c}\beta \text {-Carotene } \\
(\mathrm{RE})\end{array}$ & $\begin{array}{c}\text { Vit.C }(\mathrm{mg}) \\
(\mathrm{mg})\end{array}$ \\
\hline HS & $2.62^{\mathrm{a}} \pm 0.01$ & $0.22^{\mathrm{a}} \pm 0.00$ & $104.17^{\mathrm{a}} \pm 0.03$ & $0.05^{\mathrm{a}} \pm 0.00$ & $265.45^{\mathrm{a}} \pm 0.01$ & $1.64^{\mathrm{b}} \pm 0.01$ & $0.33^{\mathrm{b}} \pm 0.00$ \\
DS & $2.47^{\mathrm{b}} \pm 0.01$ & $0.25^{\mathrm{a}} \pm 0.00$ & $98.80^{\mathrm{b}} \pm 0.01$ & $0.06^{\mathrm{a}} \pm 0.00$ & $277.11^{\mathrm{b}} \pm 0.00$ & $1.47^{\mathrm{b}} \pm 0.01$ & $0.29^{\mathrm{b}} \pm 0.00$ \\
FS & $2.35^{\mathrm{b}} \pm 0.01$ & $0.23^{\mathrm{a}} \pm 0.00$ & $95.43^{\mathrm{b}} \pm 0.01$ & $0.07^{\mathrm{a}} \pm 0.00$ & $266.31^{\mathrm{c}} \pm 0.02$ & $1.83^{\mathrm{c}} \pm 0.01$ & $0.27^{\mathrm{b}} \pm 0.00$ \\
\hline
\end{tabular}

$\mathrm{HS}=$ Husks soup, DS= Dried leaves soup, FS= Fresh leaves soup.

Means \pm SD of three determinations

Values at the same vertical column with different superscript letters are significantly different $(\mathrm{P}<0.05)$.

\section{Phytochemical composition of soups based on cowpea leaves and husks.}

The phytochemical and antinutrients content of the soups had similar $(\mathrm{P}>0.05)$ values. The similarity of these phytochemicals and antinutrients in the soups might be explained as follows:

(a) The most tender leaves and pods were selected to prepare the soups and

(b) The tender leaves and husks were not old enough to concentrate higher levels of the phytochemical and antinutrients that function with age.

Table 3: Phytochemical composition of cowpea leaves and husks soups per 100g portion.

\begin{tabular}{lcccc}
\hline Sample & $\begin{array}{c}\text { Tannins } \\
(\mathrm{mg})\end{array}$ & $\begin{array}{l}\text { Saponins } \\
(\mathrm{mg})\end{array}$ & $\begin{array}{l}\text { Polyphenols } \\
(\mathrm{mg})\end{array}$ & $\begin{array}{l}\text { Flavonoids } \\
(\%)\end{array}$ \\
\hline HS & $0.23^{\mathrm{a}} \pm 0.00$ & $0.14^{\mathrm{a}} \pm 0.00$ & $1.24^{\mathrm{a}}{ }^{\mathrm{b}} \pm 0.01$ & $0.24^{\mathrm{a}} \pm 0.01$ \\
DS & $0.22^{\mathrm{a}} \pm 0.00$ & $0.15^{\mathrm{a}} \pm 0.00$ & $1.26^{\mathrm{b}} \pm 0.01$ & $0.28^{\mathrm{a}} \pm 0.00$ \\
FS & $0.26^{\mathrm{a}} \pm 0.00$ & $0.14^{\mathrm{a}} \pm 0.00$ & $1.23^{\mathrm{a}} \pm 0.00$ & $0.23^{\mathrm{a}} \pm 0.00$ \\
\hline
\end{tabular}

Key: HS= Husks soup, $\mathrm{DS}=$ Dried leaves soup, $\mathrm{FS}=$ Fresh leaves soup.

Means \pm SD of three determinations

Values at the same vertical column with different superscript letters are significantly different $(\mathrm{P}<0.05)$.

Antinutrient composition of soups based on cowpea leaves and husks soups.

Surprisingly, phytate, oxalate and haemaglutinin had comparable values for the three soups (Table 4) $(\mathrm{P}>0.05)$.

Table 4: Antinutrients composition of soups based on cowpea leaves and husks per $100 \mathrm{~g}$

\begin{tabular}{clcc}
\hline Sample & $\begin{array}{l}\text { Phytate } \\
(\mathrm{mg})\end{array}$ & $\begin{array}{c}\text { Oxalate } \\
(\mathrm{mg})\end{array}$ & $\begin{array}{c}\text { Heamagglutinin } \\
(\mathrm{Hu} / \mathrm{g})\end{array}$ \\
\hline FL & $0.45^{\mathrm{a}} \pm 0.01$ & $0.14^{\mathrm{a}} \pm 0.00$ & $0.64^{\mathrm{a}} \pm 0.00$ \\
DL & $0.55^{\mathrm{a}} \pm 0.08$ & $0.12^{\mathrm{a}} \pm 0.00$ & $0.54^{\mathrm{a}} \pm 0.01$ \\
$\mathrm{HU}$ & $0.53^{\mathrm{a}} \pm 0.00$ & $0.13^{\mathrm{a}} \pm 0.01$ & $0.50^{\mathrm{a}} \pm 0.00$ \\
\hline
\end{tabular}

$\mathrm{FL}=$ fresh leaves, $\mathrm{DL}=$ Dried leaves, $\mathrm{HU}=$ Husks of cowpea.

Means \pm SD of three determinations

Values at the same vertical column with different superscript letters are significantly different $(\mathrm{P}<0.05)$. 
The low levels of all the phytochemicals and antinutrients in all the soups (Table 4) suggest that they would perform their various functions very well when consumed in the soups. It is known that, when these food toxicants and antinutrients are present in low levels, the efficacy of phytochemicals to fight various diseases and high levels of serum cholesterol inimical to health are higher.

\section{Organoleptic evaluation for soups based on cowpea leaves and husks.}

The sensory values for the fresh leaves soup were high and ranged from 6.10 to 6.57. The values were lower $(\mathrm{P}<0.05)$ than those of the dried leaves (DS) and the husk (HS) $(7.13$ to 7.70 and 7.11 to 7.70 , each). When the four attributes for the FS, DS and HS soups were summed up, the DS soup had the highest value (29.86) followed by the HS soups (29.09) (Table 4). The close values (29.86 and 29.09) were an indication that DS and HS soups were equally accepted by the panelists.

Table 5: Mean scores for organoleptic test for soups based on cowpea leaves and husks.

\begin{tabular}{llccc}
\hline Sample & Colour & Taste & Consistency & General acceptability \\
\hline FS & $6.57^{\mathrm{a}}$ & $6.17^{\mathrm{a}}$ & $6.50^{\mathrm{a}}$ & $6.10^{\mathrm{a}}$ \\
DS & $7.53^{\mathrm{b}}$ & $7.70^{\mathrm{b}}$ & $7.13^{\mathrm{a}}$ & $7.50^{\mathrm{b}}$ \\
HS & $7.70^{\mathrm{b}}$ & $7.18^{\mathrm{b}}$ & $7.20^{\mathrm{a}}$ & $7.11^{\mathrm{b}}$ \\
\hline
\end{tabular}

$\mathrm{HS}=$ Husks soup, $\mathrm{DS}=$ Dried leaves soup, $\mathrm{FS}=$ Fresh leaves soup.

Means \pm SD of three determinations

Values at the same vertical column with different superscript letters are significantly different $(\mathrm{P}<0.05)$.

The comparable attributes for the three soups based on fresh leaves (6.10 to 6.57) ( Table 5) meant that, these soups scored more than one half of the 9- point of the hedonic scale. On the other hand, the higher scores for the soups based on dried leaves and husks were better appreciated for all the attributes of the soups. When the values were summed up and compared, the soups based on dried leaves had an edge over that based on dried husks (7.47 vs. 7.30, each). This meant that judges slightly preferred dried leaves soup to husk soup. The soups of both processed leaves, husks and the fresh leaves are good sources of protein, fibre, carbohydrate, iron calcium, phosphorus and appreciable phytochemicals. The soups were generally acceptable. Cowpea leaves and husks soups have promising food potentials and need promotion and diversification.

\section{Conclusion}

As judged by the results, the vegetative parts of cowpea (leaves and husks) have promising nutritional attributes. The soups of both processed leaves, husks and the fresh leaves are good sources of protein, fibre, carbohydrate, iron calcium, phosphorus and appreciable phytochemicals. The low level of antinutrients and food toxicant content are of nutritional importance. This is because; the presence of antinutrients reduces bioavailability of nutrients. The soups were generally acceptable. The consumption of these vegetative parts of cowpea (leaves and husks) can serve as good sources of nutrients for vegetarians, school children, pregnant women and all adults.

\section{References}

[1]. $\quad$ K .Ahenkora,., H.K. Adu-Dapaah., A. Agyemang. Selected nutritional components and sensory attributes of cowpea (Vigna unguiculata L. Walp). Plant Foods for Human Nutrition, 52, 1998, 5221-5229.

[2]. T. A. Ohler, S. S. Nielson and C. A. Mitchell. Varying Plant Density and Harvest Time to optimize Cowpea Leaf Yield and Nutrient Content. Hortscience, 31(2) 1996,193-197.

[3]. J.K. Imungi, N.N. Potter, Nutrient contents of raw and sensory properties of canned and stored cowpea leaves. Nutrition Reports Int. 31, 1983, 21-34

[4]. PS Mamiro, A .M. Mbwaga, D.P. Mamiro, A.W.. Mwanri, J.L.Kinabo. Nutritional quality and utilization of local and improved cowpea varieties in some regions in Tanzania. African Journal of Food, Agriculture, Nutrition and Development. 2011,p51988 [online] www.thefreelibrary.com

[5]. AOAC. Official methods of Analysis of the Association of Official Analytical Chemists (Washington D.C. 18 $8^{\text {th }}$ ed, 2005). 